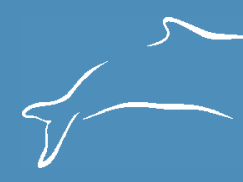

\begin{tabular}{|c|c|}
\hline \multicolumn{2}{|c|}{ Article Info } \\
\hline Manuscript type & Article \\
\hline \multicolumn{2}{|l|}{ Article history } \\
\hline Received & 06 June 2015 \\
\hline Received in revised form & 27 December 2015 \\
\hline Accepted & 28 December 2015 \\
\hline Available online & 30 December 2017 \\
\hline \multicolumn{2}{|c|}{ Responsible Editor: Fernando Félix } \\
\hline $\begin{array}{l}\text { Citation: O'Hern, J.E., S } \\
\text { Slowey, N., Alarcon Rual } \\
\text { mammal distribution in } \\
\text { opportunity as a means o } \\
\text { Latin American Journal of } \\
\text { https://doi.org/10.5597/l }\end{array}$ & $\begin{array}{l}\text { ey, M., Jean-Smith, K., Biggs, D., } \\
\text { ond Duncan, R. (2017) Marine } \\
\text { dor: surveys aboard a ship of } \\
\text { nitoring relative abundance. } \\
\text { uatic Mammals 12(1-2): 28-39. } \\
00235\end{array}$ \\
\hline
\end{tabular}

\section{Marine mammal distribution in Ecuador: surveys aboard a ship of opportunity as a means of monitoring relative abundance} Julia E. O’Hern ${ }^{\dagger, *}$, Michelle Sculley ${ }^{\ddagger}$, Kerri Jean-Smith ${ }^{\S}$, Douglas Biggs', Niall Sloweys, Daniela Alarcon Ruales" and Roxanne Duncan ${ }^{\$}$

†The Marine Mammal Center. P.O. Box 778, 95039 Moss Landing, CA, USA JIMAR, University of Hawai’i, NOAA PIFSC. 1845 Wasp Blvd., 96818 Honolulu, HI, USA

${ }^{\S}$ Department of Veterinary Pathobiology, Texas A\&M University. 400 Raymond Stotzer Parkway, 77843 College Station, TX, USA 'Department of Oceanography, Texas A\&M University. 797 Lamar St, 77843 College Station, TX

"Universidad San Francisco de Quito. Avenida Alsacio Northia frente a Playa Mann, Isla San Cristobal, Galapagos, Ecuador ${ }^{\$}$ Galway-Mayo Institute of Technology, Marine and Freshwater Research Center. Dublin Road, H91 T8NW Galway, Ireland *Corresponding author, email: ohern.julia@gmail.com

Abstract. Five marine mammal surveys between 2008 and 2011 were conducted aboard the Buque de Investigación Orion (the research vessel for the Oceanographic Institute of the Ecuadorian Navy) within oceanic waters adjacent to mainland Ecuador and the Galápagos Islands. The surveys dedicated extensive time in deep, offshore waters where cetaceans were not densely present. Sightings of 12 species were compared with an earlier survey aboard the B/I Orion in 2001 as well as with a subset of published data from three NOAA STAR (Stenella Abundance Research) surveys between 1999 and 2003. Additionally, a small boat, near-shore survey, was conducted during June 2010 among and near the Galápagos Islands. Encounter rates ranged annually from 0.012 cetacean $/ \mathrm{km}$ to 0.027 cetacean $/ \mathrm{km}$. The highest encounter rate aboard the B/I Orion took place during the April 2009 survey. In order to compare sighting rates between the B/I Orion and NOAA platforms, the average effective half-strip widths were used to determine encounter rates per area effectively searched. A zonation within the study region was observed between odontocete and balaenopterid cetaceans as well as between striped (Stenella coeruleoalba) and short-beaked common dolphins (Delphinus delphis). Several methodological aspects of surveys and geographical features that may influence encounter rates and subsequent abundance estimates are discussed. This study demonstrates that vessels of opportunity provide a valuable means of studying open-ocean and coastal distributions of marine mammals. Possible methodological improvements, such as the use of high-power binoculars, that could increase the absolute number of sightings, the efficiency of these opportunistic surveys, and improve the sighting rates of more evasive species are discussed.

Resumo. Cinco levantamentos de mamíferos marinhos foram realizados entre 2008 e 2011 a bordo do Navio de Pesquisa Orion (a embarcação de pesquisa do Instituto Oceanográfico da Marinha Equatoriana) em águas oceânicas adjacentes ao Equador continental e Ilhas Galápagos. Os levantamentos dedicaram extensos períodos a águas profundas de alto mar, onde os cetáceos não apresentam densas populaçóes. Avistagens de 12 espécies foram comparadas a resultados de levantamento anterior realizado a bordo do mesmo N/P Orion em 2001, assim como a um subconjunto de dados publicados a partir de três levantamentos NOAA STAR (Pesquisa de Abundância de Stenella) conduzidos entre 1999 e 2003. Além disso, um levantamento próximo à costa a bordo de pequena embarcação foi conduzido durante junho de 2010 nas Ilhas Galápagos e proximidades. As taxas de encontro variaram anualmente de 0,02 cetáceo/ $/ \mathrm{km}$ a 0,027 cetáceo $/ \mathrm{km}$. A maior taxa de encontro registrada a bordo do B/P Orion ocorreu durante o levantamento de abril de 2009. A fim de comparar taxas de avistagem obtidas pelo B/P Orion e as plataformas NOAA, as larguras médias efetivas de meia banda foram usadas para determinar as taxas de encontro por área efetivamente pesquisada. Uma zonação foi observada dentro da área de estudo entre cetáceos odontocetos e balenopterídeos, assim como entre golfinhos- 
listrados (Stenella coeruleoalba) e golfinhos-comuns-de-bico-curto (Delphinus delphis). Vários aspectos metodológicos dos levantamentos e características geográficas que podem influenciar as taxas de encontro e subsequentes estimativas de abundância são discutidos. Este estudo demonstra que plataformas de oportunidade oferecem um valioso meio para o estudo de distribuição de mamíferos marinhos, costeira e de mar aberto. Discutem-se possíveis melhorias metodológicas, como o uso de binóculos de alta potência que podem aumentar o número absoluto de avistagens e a eficiência desses levantamentos oportunísticos, e aprimorar as taxas de avistagem de espécies mais evasivas.

\section{Introduction}

The Eastern Tropical Pacific (ETP) is a biologically productive region of the world's oceans. A small portion of this region stretching westward from the South American continent, the Equatorial Pacific, is responsible for 18-56\% of the global ocean new biological production (Chavez and Barber, 1987). Marine mammals, as large and generally apex predators that can consume hundreds of kilograms of marine prey each day, play an important role in this ecosystem and have been impacted for centuries through anthropogenic influences. Regular surveys to assess marine mammal abundance and distribution are vital for furthering our understanding of both the distribution and ecological role of these animals and the impacts of anthropogenic activities. Marine mammal and human interaction within the ETP began in the $18^{\text {th }}$ and $19^{\text {th }}$ centuries with the advent of the region's whaling industry (Townsend, 1935). Whaling expeditions continued through the early $20^{\text {th }}$ century, but scientific observation of cetaceans did not begin until the 1950s and 1960s (e.g. Clarke, 1962; Loesh, 1966).

The coastlines within the area now encompassing the Galápagos Marine Reserve (GMR) as well as the Ecuador mainland are biologically productive habitat for marine mammals. Dedicated studies of the sperm whale (Physeter macrocephalus) population continued around the Galápagos Islands and Ecuador mainland coast in the 1980s (e.g. Whitehead and Waters, 1992; Smith and Whitehead, 2000). From 1988 to 1989 the $R / V$ Siben surveyed sperm whales throughout the Galápagos Archipelago, and in 19931994 and 2000 the $R / V$ Odyssey conducted multiple marine mammal surveys near this same region ${ }^{1,2}$. More recent survey work within the GMR utilized ecotourism vessels as platforms of opportunity and provided detailed information on cetacean species composition within the Reserve (Denkinger et al., 2013). The migratory population of humpback whales (Megaptera novaeangliae) can be found within the GMR as

\footnotetext{
${ }^{1}$ Lyrholm, T., Kerr, I., Galley, L. and Payne, R. (1992) Report of the Expedición Siben, Ecuador 1988/89. Final Report submitted by the Whale Conservation Institute to the Charles Darwin Research Station and the Galápagos National Park Service. Puerto Ayora, Islas Galápagos, Ecuador.

${ }^{2}$ Palacios, D.M. (1999) Final report submitted to Galápagos National Park Service and Charles Darwin Research Station: Marine mammal research in the Galápagos Islands: The 1993-94 Odyssey Expedition. Puerto Ayora, Islas Galápagos, Ecuador. [Available from Ocean Alliance, 191Weston Rd., Lincoln, MA 01773, USA]
}

well as along the mainland coast from May through September (Félix and Haase, 2001).

A coastal population of common bottlenose dolphins (Tursiops truncatus) continues to be well documented along the mainland coast and inside the mouth of the Guayaquil River (e.g. Félix, 1997). These coastlines serve as breeding and mating grounds for the humpback whales and bottlenose dolphins (Scheidat et al., 2000; Félix and Haase, 2001; 2005; Alava et al., 2005).

Information on cetacean presence in offshore waters, however, is more difficult to obtain than in coastal and insular waters, but nevertheless it is important to fully understand their distributions and monitor the recovery of species impacted by human activities. For example, results from Félix et al. (2011) suggest at least some degree of relatedness between members of the mainland coastal humpback population and those humpbacks found across a nearly thousand mile stretch of ocean within the Galápagos Archipelago. From the 1980s through the present, NOAA Southwest Fisheries Science Center has conducted extensive and dedicated marine mammal surveys throughout the ETP, including areas within Ecuadorian waters, to assess the effects of the yellowfin tuna (Thunnus albacares) purse seine fishery on dolphin populations (e.g. Au and Perryman, 1985; Fiedler and Reilly, 1994; Gerrodette and Forcada, 2005) ${ }^{3,4,5}$. The STAR surveys provided reliable abundance estimates for cetacean species throughout the ETP region that encompasses Ecuador and the GMR.

Marine mammal surveys conducted aboard the B/I Orion in August 2000 and September 2001 sighted seven species of cetaceans within the oceanic and coastal waters of Ecuador. The absence of sperm whales, currently considered vulnerable by the International Union for the Conservation of Nature

${ }^{3}$ Gerrodette, T. and Palacios, D.M. (1996) Estimates of cetacean abundance in EEZ waters of the Eastern Tropical Pacific. National Marine Fisheries Service, Southwest Fisheries Science Center Administrative Report LJ-96-10. [Available from SWFSC <swfsc.noaa.gov>]

${ }^{4}$ Jackson, A., Gerrodette, T., Chivers, S., Lynn, M., Olson, P. and Rankin, S. (2004) Marine mammal data collected during a survey in the Eastern Tropical Pacific Ocean aboard the NOAA ships McArthur and David Starr Jordan, July 29-December 10, 2003. US Department of Commerce, National Oceanic Atmospheric Administration, Southwest Science Fisheries Center, NOAATM-SWFSC-366. [Available from SWFSC <swfsc.noaa.gov>]

${ }^{5}$ Gerrodette, T., Watters, G., Perryman, W. and Balance, L. (2008) Estimates of 2006 dolphin abundance in the Eastern Tropical Pacific, with revised estimates from 1986-2003. US Department of Commerce, National Marine Fisheries, Southwest Science Fisheries Center, NOAA-TM-NMFSSWFSC-422. [Available from SWFSC <swfsc.noaa.gov >] 


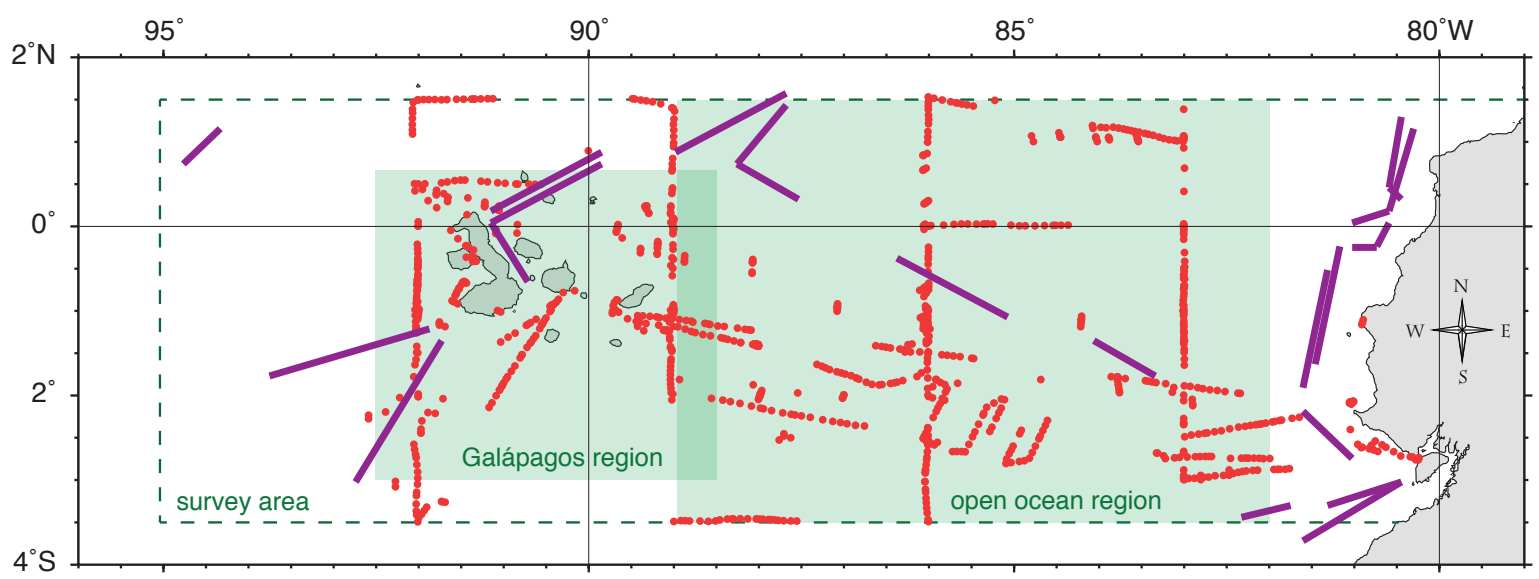

$4^{\circ} \mathrm{S}$

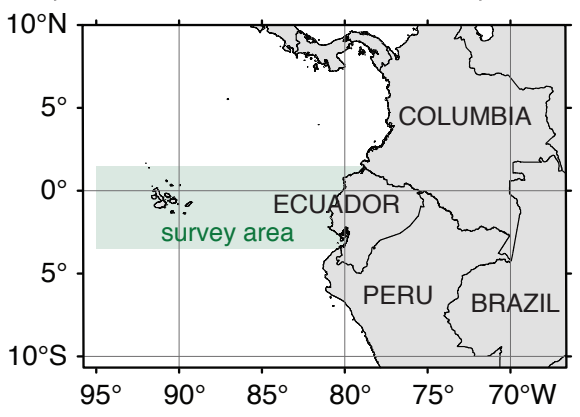

(Taylor et al., 2008), was noted as the most significant departure from previous mammal surveys (Clarke et al., 2001) and supported the findings of Whitehead et al. (1996) that also observed a rapid decline in the sperm whale population near the Galápagos Islands prior to and during this time period. By including marine mammal surveys in annual oceanographic cruises aboard a ship of opportunity, B/I Orion (the research vessel for Ecuador's Instituto Oceanográfico de la Armada, INOCAR), remote and oceanic areas of Ecuadorian waters were regularly surveyed over several years (2008-2011). The results from these surveys are compared to sightings and survey work aboard three NOAA Stenella Abundance Research (STAR) Surveys ${ }^{4,6,7}$, and utilized in conjunction with two other surveys to provide an overall summary of marine mammal presence within oceanic waters adjacent to the coastlines of Ecuador. A summary list of cruises is presented in Table 1. The results also inform improvements that can be made to ships-of-opportunity marine mammal surveys.

${ }^{6}$ Kinzey, D., Gerrodette, T., Barlow, J., Dizon, A., Perryman, W. and Olson, P. (2000) Marine mammal data collected during a survey in the Eastern Tropical Pacific Ocean aboard the NOAA ships McArthur and David Starr Jordan, July 28-December 9, 1999. US Department of Commerce, National Oceanic Atmospheric Administration, National Marine Fisheries, Southwest Science Fisheries Center, NOAA-TM-NMFS-SWFSC-293. [Available from SWFSC <swfsc.noaa.gov>]

${ }^{7}$ Kinzey, D., Gerrodette, T., Dizon, A., Perryman, W., Olson, P. and Rankin, S. (2001) Marine mammal data collected during a survey in the Eastern Tropical Pacific Ocean aboard the NOAA ships McArthur and David Starr Jordan, July 28-December 9, 2000. US Department of Commerce, National Oceanic Atmospheric Administration, National Marine Fisheries, Southwest Science Fisheries Center, NOAA-TM-NMFS-SWFSC-303. [Available from SWFSC <swfsc.noaa.gov $>$ ]

\section{Methods}

\section{Field Surveys}

Between 2008 and 2011, marine mammal surveys were conducted aboard a vessel of opportunity as a collaboration between Texas A\&M University and INOCAR. The B/I Orion is a $70 \mathrm{~m}$ oceanographic vessel for INOCAR and maintains average survey speeds of 7-10 knots. In 2001, Clarke et al. (2001) conducted a similar marine mammal survey aboard the B/I Orion. During 2001-2011, cruises of the B/I Orion followed pre-determined North-South tracklines and East-West transit lines and made regular oceanographic measurements. These surveys were conducted within a region bounded by $1^{\circ} 30^{\prime} \mathrm{N}, 3^{\circ} 30^{\prime} \mathrm{S}$ and $79^{\circ} 0^{\prime} \mathrm{W}, 95^{\circ} 0^{\prime} \mathrm{W}$ and encompassing $895480 \mathrm{~km} 2$ (Figure 1).

The visual surveys were conducted from the flying bridge, $9.8 \mathrm{~m}$ above the waterline (measured distance from the average observer's eye height while standing), during all daylight hours (approximately 06:00-18:30h). Effort was suspended when the ship stopped for CTD (Conductivity Temperature Depth) measurements, 30-minute meal times, and times when weather conditions did not permit a clear view of the sea surface (heavy rain and Beaufort sea states $>5$ ). Observers numbered 2-4 depending on volunteers available (number and skill level of observers on watch were recorded with observing conditions). Observers used Bushnell $7 \times 50 \mathrm{~mm}$ binoculars to scan continuously from forward of the ship out to each beam $\left(90^{\circ}\right.$ from the bow to port and starboard) and from the ship hull to the horizon. Field observation during the 2008-2011 surveys followed, as closely as possible, the line-transect methods described in Mullin and Fulling 
Table 1. Summary of survey cruises within the Ecuador study region 1991-2011.

\begin{tabular}{|l|c|c|}
\hline Year & $\begin{array}{c}\text { Dates of Effort in } \\
\text { Survey Area }\end{array}$ & Ship Name \\
\hline 1999 & $\begin{array}{c}\text { 12 Oct, } 18 \text { Oct, } \\
8 \text { Nov to } 10 \text { Nov }\end{array}$ & $R /$ Jordan \\
\hline 2000 & $\begin{array}{l}\text { 6 Oct to } 10 \text { Oct, } \\
5 \text { Nov to } 9 \text { Nov }\end{array}$ & B/I Orion \\
\hline 2001 & 17 Sep to 8 Oct & $R /$ V McArthur II $~$ \\
\hline 2003 & $\begin{array}{c}\text { 10 Oct to } 12 \text { Oct, } \\
7 \text { Nov to } 9 \text { Nov }\end{array}$ \\
\hline 2008 & 23 Sep to 10 Oct & B/I Orion \\
\hline 2009 & 2 Apr to 21 Apr & B/I Orion \\
\hline 2009 & 7 Oct to 30 Oct & B/I Orion \\
\hline 2010 & 4 Jun to 14 Jun & fishing boats \\
\hline 2010 & 25 Sep to 9 Oct & B/I Orion \\
\hline 2011 & 25 Sep to 9 Oct & B/I Orion \\
\hline
\end{tabular}

(2004) and those protocols from other ships-of-opportunity studies as in Palacios et al. (2009) and Williams et al. (2006). Field methods employed during the 2001 B/I Orion cruise and NOAA SWFSC STAR cruises are described in Clarke et al. (2001) and Gerrodette et al. ${ }^{5}$, respectively. There were several important differences between cruises aboard the $B / I$ Orion and NOAA ships. First, the NOAA STAR cruises are dedicated marine mammal surveys where the ships diverted from tracklines to approach and identify groups of animals. In contrast, B/I Orion surveys were conducted in passing mode as the ship transited to the sites of hydrographic stations and therefore the ship did not deviate from its course to approach sighted groups of cetaceans. NOAA STAR cruises were staffed by a large number of trained observers that rotated watches on regular intervals. These observers used $25 \times 150 \mathrm{~mm}$ 'Big Eye' binoculars that enabled them to reliably observe cetaceans over a much greater distance (a larger half-strip width) than the smaller $7 \times 50 \mathrm{~mm}$ binoculars used by observers on the $B / I$ Orion. The $B / I$ Orion cruises were also used as training cruises for graduate students new to marine mammal observing, with at least one expert observer (with both theoretical and field training aboard NOAA line transect marine mammal surveys) working with the student observers during each shift.

During the June 2010 small boat survey (Figure 2), a $50 \mathrm{ft}$. fishing boat, Lancha Cucaracha, was chartered out of Puerto Ayora, Santa Cruz, Galápagos for a three day survey between Puerto Ayora, Isla Floreana, and Puerto Villamil, Isabela. Observers watched from the flying bridge helm during daylight hours while traveling at an average speed of 10 knots. While handheld 7x50 binoculars were available, naked-

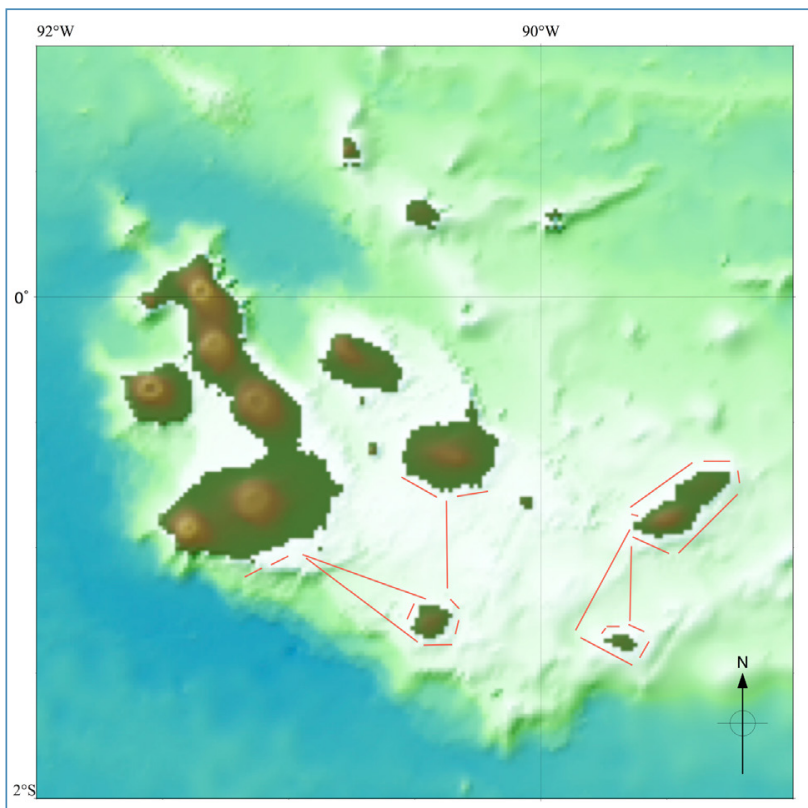

Figure 2. Survey tracks for a small boat survey near the Galápagos Islands, June 2010. Nine days of survey effort are shown.

eye observation was more common. Sighting conditions (Beaufort sea state, cloud cover, sun glare) and GPS positions were noted every 30 minutes. A $65 \mathrm{ft}$ fishing vessel, Niño Ronny Jesus, was chartered out of San Cristobal for a six-day survey around San Cristobal and Española Islands. Observing conditions were better and sea state was lower, during this portion of the survey.

\section{Analytical Methods}

Data were compiled from ten separate cruises conducted over a 12-year time period (Table 1). Eight of these cruises took place during the September/October rainy season, five of which were conducted aboard the B/I Orion and three of which were conducted as part of the NOAA STAR program. Published sightings from the NOAA STAR cruises $^{4,6,7}$ were compared to sighting rates from the $B / I$ Orion. One cruise was conducted during the April dry season aboard the $B / I$ Orion and another small boat survey conducted between the Galápagos Islands took place during the month of June. These last two surveys were the only survey data utilized from seasons outside the rainy season.

The abundances of striped (Stenella coeruleoalba) and short-beaked common dolphins (Delphinus delphis) were calculated using a modified distance sampling method. Since the NOAA cruises encompassed the entire ETP, only those sightings and survey effort that occurred within our study area of $1^{\circ} 30^{\prime} \mathrm{N}, 3^{\circ} 30^{\prime} \mathrm{S}$ and $79^{\circ} 0^{\prime} \mathrm{W}, 95^{\circ} 0^{\prime} \mathrm{W}$ were used to calculate NOAA specific abundances. Published $f(0)$ values for striped and common dolphins from the NOAA STAR cruises were used when calculating abundances of these species within Ecuadorian waters. 
The computer program Distance 6.0 (Thomas et al., 2010) was used to model a probability density function from the initial sighting distances between shipboard observers and cetacean groups during the 2008 and 2011 B/I Orion cruises. Radial sighting distances were calculated according to the formula from Lerzack and Hobbes (1998), and radial distances were used to calculate the perpendicular distances between observers aboard the B/I Orion and sighted cetaceans.

$$
P=R \times \sin (\theta)
$$

where $P$ is the horizontal distance between the trackline and sighted animal and $\theta$ is the horizontal angle between the trackline and the animal.

Due to insufficient number of sightings of each species, a single probability density function or $f(0)$ was modeled for all cetacean sightings aboard the $B / I$ Orion.

A hazard rate model for sighting distances made aboard the B/I Orion was selected based on the calculated Akaike Information Criterion (AIC) values from several models considered.

$$
f(x)=1-\exp \left\{-\left(\frac{x}{b}\right)^{-c}\right\}
$$

where $\boldsymbol{x}$ is the perpendicular distance from the survey line, and $\boldsymbol{b}$ and $\boldsymbol{c}$ are constants.

The detection probability, $\boldsymbol{g}(\mathbf{0})$ is often assumed to equal 1 (that all animals on the trackline were detected). This assumption is likely an overestimation, particularly during survey effort in which the Beaufort sea state was greater than 1 or 2. Barlow (2015) calculated Beaufort specific $g(0)$ values for several cetacean species in the ETP. Published $g(0)$ values at each Beaufort state were included in abundance calculations for striped and common dolphins using B/I Orion sightings. Abundance $(N)$ was calculated from the probability density function as described in Buckland et al. (1993; 2001), where the sampling unit for these estimates was the cruise year, not individual tracklines. These abundance estimates from $B / I$ Orion sightings were compared to those calculated from sightings made during NOAA surveys.

$$
N_{\text {NOAASirveys }}=\sum_{1999}^{2003} \frac{s_{n} \times f(0)}{2 \times L} \quad N_{\text {OrionSurveys }}=\sum_{2001}^{2011} \frac{s_{n} \times f(0)}{2 \times L \times g(0)_{B}}
$$

Where $\boldsymbol{n}$ is the number of sightings of cetacean groups, $\boldsymbol{s}$ is the group size at sighting $n, \boldsymbol{f}(\mathbf{0})$ is the probability density function at zero distance from the transect line, $L$ is the total length of the transect lines, and $\boldsymbol{g}(\mathbf{0})$ is the detection probability at each discrete Beaufort sea state.

The distance from the ship at which observers could reliably spot marine mammals was calculated from the effective half-strip width. The effective half-strip width or $\mu$ is the distance from the trackline where the number of groups seen at distances greater than $\mu$ equals the number not seen at distances less than $\mu$. The half-strip width was calculated from $f(0)$ by the following, as shown in Buckland et al. (1993):

$$
\mu=\frac{1}{f(0)}
$$

This calculation assumes that all animals on the trackline were observed, which is likely an overestimation.

Sighting rates were calculated from total number of sightings divided by total kilometers surveyed within each cruise. Since low sighting numbers of individual species prevented species specific estimates, for each survey a sighting rate based on total combined cetacean sightings was calculated. This combined cetacean annual encounter rate allowed for interannual variability comparisons between cruises, seasons, and survey years.

$\frac{n}{L}$

In order to better compare sighting rates between the two different survey programs, NOAA STAR and B/I Orion, sighting rates were also calculated for each survey relative to the total trackline area that was reliably observed. The trackline area observed was calculated from $\mu$.

$$
\frac{n}{2 \times \mu \times L}
$$

The number of observers on watch, skill level of observers, cloud cover, and the Beaufort sea state displayed linear relationships with overall encounter rates. Beaufort sea state was determined to be the most significant factor influencing sighting rates and included in sighting rate estimates for relative comparisons.

$$
\frac{n}{l}=\sum \frac{1-\left(R_{a} \times a\right)}{2 \times E S W \times l}
$$

where $\boldsymbol{n}$ =number of sightings for each survey, $\boldsymbol{l}=$ length in $\mathrm{km}$ of survey effort for each survey, $\boldsymbol{a}=$ Beaufort sea state of each sighting, $\boldsymbol{R}=$ correlation coefficient between the observing condition (Beaufort sea state) and sightings for each survey, $\boldsymbol{E} \boldsymbol{S} \boldsymbol{W}=$ effective strip width $(1.7 \mathrm{~km})$.

The variance of encounter rates among surveys was calculated according to Buckland et al. (1993).

$$
\operatorname{var}\left(\frac{n}{L}\right)=\frac{\sum_{i=l}^{k} \frac{l_{i}}{L}\left(\frac{n_{i}}{l_{i}}-\frac{n}{L}\right)^{2}}{k-1}
$$

where $\boldsymbol{L}=$ total survey effort for all cruises, $\boldsymbol{n}=$ total number of sightings of all cruises, $\boldsymbol{i}=$ survey (1999-2011), $\boldsymbol{n}_{\boldsymbol{i}}=$ number of sightings for each cruise, $\boldsymbol{l}_{\boldsymbol{i}}=$ length of survey effort of each cruise, $\boldsymbol{k}=$ number of surveys.

Sighting counts were also combined across years, in order to calculate encounter rates for two different zones within the Ecuador study region (Figure 1). Sightings for an open ocean area between $82^{\circ} 0^{\prime} \mathrm{W}, 89^{\circ} 0^{\prime} \mathrm{W}$ longitude and $1^{\circ} 30^{\prime} \mathrm{N}, 3^{\circ} 30^{\prime} \mathrm{S}$ latitude were compared with those sightings surrounding the Galápagos Islands within an area defined by $88^{\circ} 54^{\prime} \mathrm{W}$ to $92^{\circ} 30^{\prime} \mathrm{W}$ and $1.0^{\circ} \mathrm{N}$ to $1^{\circ} 30^{\prime} \mathrm{S}$ (Figure 1 ). Only sightings from the September/October NOAA and B/I Orion cruises were used in this analysis, in order to avoid potential seasonal variations. 


\section{Results}

In total, 12 different species of cetaceans were identified during the ten NOAA, B/I Orion, and small boat surveys within waters between mainland Ecuador and just westward of the Galápagos Islands (Table 2). A similar composition of species of marine mammals was identified within the rainy season during September/October surveys as during those surveys conducted in the drier season of April and June (with the exception of migratory humpback whales which were present along the coasts of mainland Ecuador and the Galápagos Islands during the rainy season). Sperm whales, short-finned pilot whales (Globicephala macrorhynchus which was not distinguished visually from Globicephala melas, but based on distribution maps, all pilot whales are presumed to be of the species G. macrorhynchus), blue whales (Balaenoptera musculus) and Bryde's whales (Balaenoptera edeni) were some of the most commonly identified large cetaceans (Figures 3 and 4).

Sighting rates varied among years, seasons, and survey programs (Table 3). The effective half-strip width for surveys aboard the B/I Orion was $1.7 \mathrm{~km}$. For the NOAA surveys examined in this study, the half-strip width (as determined by averaging half-strip widths from a variety of species observed throughout the ETP during NOAA surveys) was $3.0 \mathrm{~km}$. When the NOAA and B/I Orion sighting rates are expressed as sightings per area effectively searched (transect length times twice the effective half-strip width), sighting rates throughout the study area are $13 \%$ higher during NOAA STAR surveys than surveys aboard the B/I Orion.

Table 2. Cetacean and pinniped sightings made from B/I Orion, NOAA vessels, and small boats within the Ecuador study region 1999-2011.

\begin{tabular}{|c|c|c|c|c|c|c|c|c|c|c|}
\hline Sightings per species/group & $\begin{array}{c}\text { Oct } \\
1999\end{array}$ & $\begin{array}{c}\text { Oct } \\
2000\end{array}$ & $\begin{array}{c}\text { Sep } \\
2001\end{array}$ & $\begin{array}{c}\text { Oct } \\
2003\end{array}$ & $\begin{array}{c}\text { Sep } \\
2008\end{array}$ & $\begin{array}{c}\text { Apr } \\
2009\end{array}$ & $\begin{array}{c}\text { Oct } \\
2009\end{array}$ & $\begin{array}{c}\text { Jun } \\
2010\end{array}$ & $\begin{array}{c}\text { Oct } \\
2010\end{array}$ & $\begin{array}{c}\text { Sep } \\
2011\end{array}$ \\
\hline Blue whale & 1 & 1 & 1 & 0 & 0 & 1 & 3 & 0 & 2 & 8 \\
\hline Bryde's/Sei whale & 4 & 1 & 0 & 1 & 0 & 2 & 0 & 8 & 1 & 1 \\
\hline Humpback whale & 0 & 0 & 4 & 5 & 2 & 0 & 1 & 0 & 3 & 2 \\
\hline Short-finned pilot whale & 2 & 3 & 5 & 1 & 3 & 4 & 2 & 1 & 0 & 2 \\
\hline Orca & 0 & 0 & 1 & 0 & 1 & 0 & 0 & 0 & 0 & 1 \\
\hline Sperm whale & 1 & 0 & 0 & 0 & 0 & 3 & 6 & 1 & 1 & 4 \\
\hline Bottlenose dolphin & 0 & 6 & 6 & 3 & 0 & 4 & 3 & 11 & 2 & 2 \\
\hline Common dolphin & 14 & 7 & 2 & 7 & 2 & 6 & 4 & 3 & 4 & 4 \\
\hline Pantropical spotted dolphin & 0 & 0 & 2 & 6 & 1 & 0 & 0 & 0 & 0 & 0 \\
\hline Risso’s dolphin & 0 & 1 & 0 & 0 & 0 & 0 & 0 & 0 & 0 & 1 \\
\hline Striped dolphin & 12 & 5 & 1 & 7 & 0 & 2 & 1 & 0 & 5 & 2 \\
\hline Galápagos sea lion & 0 & 0 & 0 & 0 & 24 & 18 & 11 & 83 & 8 & 8 \\
\hline Cuvier's beaked whale & 2 & 0 & 0 & 0 & 0 & 0 & 0 & 0 & 0 & 0 \\
\hline Stenella sp. & 0 & 1 & 0 & 0 & 0 & 0 & 0 & 0 & 0 & 0 \\
\hline Unidentified baleen whale & 0 & 0 & 0 & 0 & 3 & 2 & 3 & 4 & 2 & 4 \\
\hline Kogia sp. & 0 & 0 & 0 & 0 & 0 & 1 & 0 & 0 & 0 & 0 \\
\hline Unidentified beaked whale & 0 & 0 & 0 & 0 & 0 & 0 & 1 & 0 & 0 & 0 \\
\hline Unidentified large whale & 0 & 2 & 0 & 1 & 3 & 0 & 7 & 3 & 5 & 7 \\
\hline Unidentified dolphin & 13 & 0 & 7 & 4 & 10 & 48 & 7 & 4 & 6 & 7 \\
\hline Unidentified odontocete & 0 & 0 & 1 & 0 & 0 & 4 & 1 & 0 & 4 & 2 \\
\hline Unidentified small whale & 1 & 0 & 0 & 1 & 8 & 0 & 0 & 0 & 0 & 0 \\
\hline Unidentified ziphiid & 4 & 1 & 0 & 0 & 0 & 0 & 0 & 0 & 0 & 0 \\
\hline Unidentified mesoplondont & 4 & 3 & 0 & 0 & 0 & 0 & 0 & 0 & 0 & 0 \\
\hline
\end{tabular}



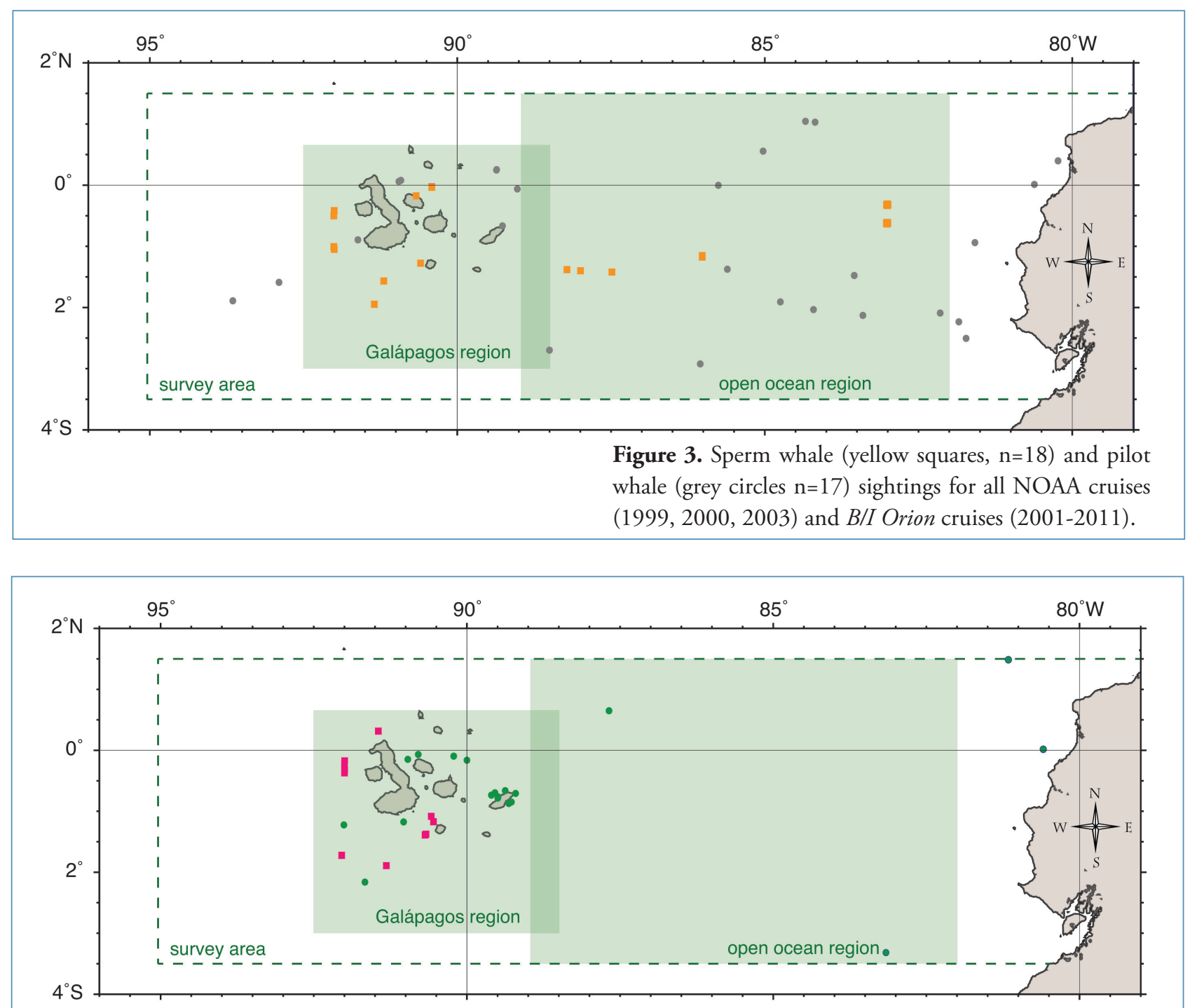

Figure 4. Blue whale (fuchsia squares $n=16$ ) and Bryde's whale (green circles $\mathrm{n}=15$ ) sightings for all NOAA cruises (1999, 2000, 2003) and B/I Orion cruises (2001-2011).

The highest sighting rate took place in 1999, 0.013 animal $/ \mathrm{km}$ in $1999(R / V$ Jordan). The lowest rate was also during a NOAA cruise in 2003, $0.0038 \mathrm{animal} / \mathrm{km}$ in 2000 ( $R / V$ McArthur). The 2000 cruise only surveyed areas just off the Ecuadorian coast (within our study area), which more likely explains the low sighting rate, rather than true interannual variation.

During cruises aboard the B/I Orion in September/ October of 2009 and 2010, sighting rates were fairly similar, $0.017 \mathrm{animal} / \mathrm{km}$ (CI 0.011-0.021). The sighting rate in September 2011, however, was 1.5 time the rate in September 2008, $0.021 \mathrm{animal} / \mathrm{km}$ (CI 0.017-0.026) compared to 0.014 animal/km (CI 0.0090-0.019) in 2008. The survey during April 2009 had the highest sighting rate for surveys made aboard the B/I Orion, $0.027 \mathrm{animal} / \mathrm{km}$ (CI 0.022-0.031). The sighting rate during April 2009 is significantly greater than the encounter rates during all September/October cruises with the exception of the 2011 cruise.
Sighting conditions (Beaufort sea state, cloud cover, glare) as well as the individuals working as observers varied among survey cruises. When sightings were weighted to account for the Beaufort sea state, the April 2009 sighting rate is still statistically different from the September/October cruises, excluding the 2011 cruise.

The mean estimated group size of cetacean groups also varied between survey programs. Mean group size (based on visual estimates made by observers) was 26 on B/I Orion surveys. The mean group size during NOAA surveys in this region was 69 . Mean group size for common dolphins was two-thirds lower during B/I Orion (56.6) than during NOAA surveys (170). For striped dolphins, B/I Orion mean group size (42.8) was only one fifth lower than NOAA mean group size estimates (53.2).

Cetaceans were sighted about every $32 \mathrm{~km}$ traveled during the June 2010, small-boat survey near the Galápagos Islands. Given that the small boat was a very different observing 
Table 3. Summary of encounter rates from B/I Orion and NOAA vessels within the Ecuador study region 1999-2011. Area effectively searched refers to the trackline of search effort multiplied by twice the effective strip width. The observing condition corrections include adjustments for Beaufort sea state and number of observers on watch. Encounter rates that were adjusted for observing conditions should be used for relative comparisons between B/I Orion surveys.

\begin{tabular}{|c|c|c|c|c|c|c|c|c|c|}
\hline Survey & $\begin{array}{c}\text { Encounter } \\
\text { rate (\# } \\
\text { sightings/ } \\
\text { km survey } \\
\text { effort ) }\end{array}$ & $\begin{array}{c}95 \% \\
\text { CI }\end{array}$ & $\begin{array}{l}\text { Encounter } \\
\text { rate per area } \\
\text { effectively } \\
\text { searched }\end{array}$ & $\begin{array}{c}95 \% \\
\text { CI }\end{array}$ & $\begin{array}{c}\text { Encounter rate } \\
\text { per area effectively } \\
\text { searched adjusted } \\
\text { for sea state }\end{array}$ & $\begin{array}{c}95 \% \\
\text { CI }\end{array}$ & $\begin{array}{l}\text { Sightings } \\
(\#)\end{array}$ & $\begin{array}{l}\text { Survey } \\
\text { effort } \\
(\mathbf{k m})\end{array}$ & $\begin{array}{l}\text { Effective } \\
\text { half-strip } \\
\text { width }\end{array}$ \\
\hline $\begin{array}{l}\text { NOAA } \\
\text { September } \\
1999\end{array}$ & 0.080 & & 0.0134 & & NA & & 57 & 709 & 3 \\
\hline $\begin{array}{l}\text { NOAA } \\
\text { September } \\
2000 \\
\end{array}$ & 0.023 & & 0.0038 & & NA & & 37 & 1626 & 3 \\
\hline $\begin{array}{l}\text { NOAA } \\
\text { September } \\
2003\end{array}$ & 0.046 & & 0.0076 & & NA & & 36 & 789 & 3 \\
\hline $\begin{array}{l}\text { September/ } \\
\text { October } \\
2008\end{array}$ & 0.014 & $\begin{array}{c}0.0090- \\
0.019\end{array}$ & 0.0041 & $\begin{array}{l}0.0027- \\
0.0054\end{array}$ & 0.0067 & $\begin{array}{c}0.0043- \\
0.0091\end{array}$ & 34 & 2396 & 1.7 \\
\hline $\begin{array}{l}\text { April } \\
2009\end{array}$ & 0.027 & $\begin{array}{l}0.022- \\
0.031\end{array}$ & 0.0078 & $\begin{array}{l}0.0064- \\
0.0092\end{array}$ & 0.012 & $\begin{array}{c}0.0096- \\
0.014\end{array}$ & 76 & 2854 & 1.7 \\
\hline $\begin{array}{l}\text { October } \\
2009\end{array}$ & 0.017 & $\begin{array}{l}0.011- \\
0.021\end{array}$ & 0.0047 & $\begin{array}{l}0.0033- \\
0.0061\end{array}$ & 0.0062 & $\begin{array}{c}0.0038- \\
0.0086\end{array}$ & 42 & 2552 & 1.7 \\
\hline $\begin{array}{l}\text { September/ } \\
\text { October } \\
2010\end{array}$ & 0.017 & $\begin{array}{l}0.011- \\
0.021\end{array}$ & 0.0047 & $\begin{array}{c}0.0033-1 \\
0.006\end{array}$ & 0.0071 & $\begin{array}{c}0.0047- \\
0.0095\end{array}$ & 39 & 1389 & 1.7 \\
\hline $\begin{array}{l}\text { September/ } \\
\text { October } 2011\end{array}$ & 0.021 & $\begin{array}{l}0.017- \\
0.026\end{array}$ & 0.0063 & $\begin{array}{l}0.0049- \\
0.0077\end{array}$ & 0.011 & $\begin{array}{c}0.0086- \\
0.013\end{array}$ & 35 & 2111 & 1.7 \\
\hline
\end{tabular}

platform than the $B / I$ Orion, these surveys were mainly intended to provide additional information on species composition near the islands outside the usual September/ October survey months. Sighting data collected from open ocean habitat for all $B / I$ Orion and NOAA cruises between $82^{\circ} 0^{\prime} \mathrm{W}$ and $89^{\circ} 0^{\prime} \mathrm{W}$ resulted in sighting rates one half of those within waters near the Galápagos $(0.0073$ sighting $/ \mathrm{km}$, $\mathrm{CV}=0.36$ compared to 0.015 sighting $/ \mathrm{km}, \mathrm{CV}=0.24$ ).

Galápagos sea lions were the only other species of marine mammal sighted during surveys aboard the B/I Orion (Figure 5). While pinnipeds are difficult to identify at sea, the larger size and more robust heads of the Galápagos sea lion generally permitted confident identifications by the experienced observers onboard. Photographs were often used to confirm identifications. However, given that many of these observations were made by volunteers and students still in training, it is possible that the Galápagos fur seal (Arctocephalus galapagoensis), which is known to inhabit the islands, particularly rocky outcroppings, was confused with the sea lions. These sightings occurred mainly near the Galápagos Islands, and were often associated with groups of bottlenose dolphins. Only two sightings of sea lions were made outside the Galápagos marine area, near $2^{\circ} 0$ 'S: one sighting of a dead sea lion floating at the surface in the open ocean and one sighting just offshore of the mainland coast. These sightings were in similar areas as open ocean balaenopterid sightings.

Striped dolphins are more evenly distributed across latitudes within the study region than common dolphins. Common dolphins were more frequently sighted in the more southerly latitudes than striped dolphins (Figure 6).

The latitudinal and geographical variation in distribution observed between striped and common dolphins can also be seen in broader taxonomic groupings. In general, odontocete cetaceans, which feed primarily on nektonic species within and well below the photic layer, were found throughout the study area. Balaenopterid whales, which feed primarily within the photic zone of the ocean on plankton and small nektonic species, were generally observed along the Ecuadorian coast and near the Galápagos Islands, but sparsely north of $1^{\circ} \mathrm{N}$ and south of $2^{\circ} \mathrm{S}$ latitudes (Figure 7).

Two of the most commonly sighted cetacean species were short-beaked common dolphins and striped dolphins. 


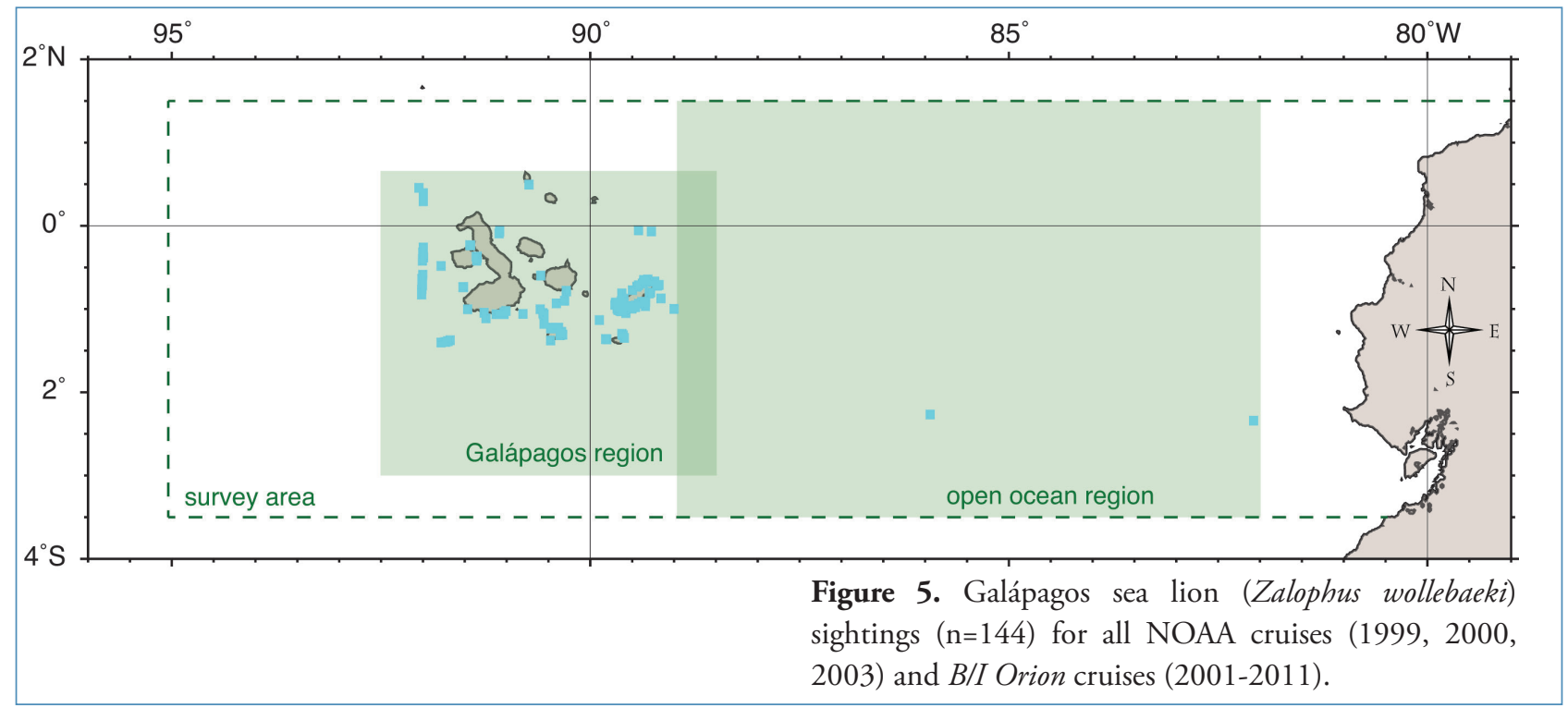

Ferguson and Barlow ${ }^{8}$ estimated mesoscale density of cetaceans based on line-transect surveys conducted throughout the ETP between 1986 and 1996. Abundance estimates were made for gridded subsections of the ETP. Based on the summed abundance estimates for those subsections that encompass our Ecuador study area, Ferguson and Barlow ${ }^{9}$ predict an abundance of 269686 (the CV for each subsection ranges from 0.0678-0.2474) striped dolphins and 1390943 (the $\mathrm{CV}$ for each subsection ranges from 0.74-2.74) common dolphins within our Ecuador study area. These results agree closely with abundance estimates calculated using sighting data from NOAA cruises 1999-2003. Striped dolphins number $266050(\mathrm{CV}=0.214)$ and common dolphins number $1031000(\mathrm{CV}=0.273)$.

Using the more recent sighting data collected by $B / I$ Orion (September/October of 2008-2011) within the Ecuador study area yielded abundance estimates for striped dolphins of 47640 $(\mathrm{CV}=0.173)$ and common dolphins of $138800(\mathrm{CV}=0.206)$.

\section{Discussion}

Oceanic and coastal waters adjacent to Ecuador provide biologically productive habitat for a wide variety of marine mammals. While the abundance of cetacean species appears to fluctuate between years and possibly between seasons, the cetacean species composition is fairly consistent. The only species demonstrating definitive seasonal affiliation is the humpback whale. Multiple sightings of humpback whales were mother/calf pairs, both near the mainland and Galápagos coasts. Other balaenopterid whales may have similar seasonal patterns, however most of the marine mammal survey data available has been obtained during the rainy season months of September and October. The only surveys conducted outside

$\overline{{ }^{8} \text { Ferguson, M.C. and Barlow, J. (2001) Spatial distribution and density }}$ of cetaceans in the Eastern Tropical Pacific Ocean based on summer/fall research vessel surveys in 1986-96. SWFSC Administrative Report No. LJ01-04. 61pp plus addendum. [Available from SWFSC, $8604 \mathrm{La}$ Jolla Shores Dr., La Jolla, CA 92037, USA]

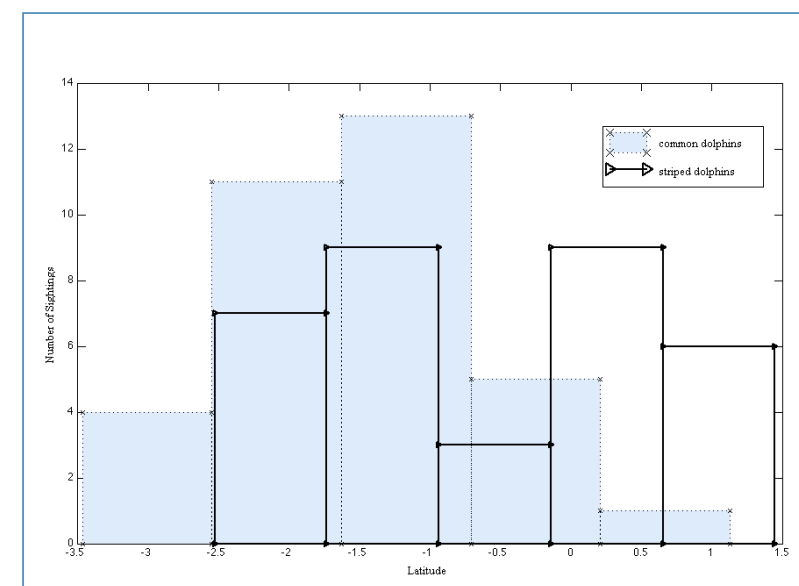

Figure 6. Number of common dolphin (blue bars) and striped dolphin (transparent bars) sightings relative to latitude during September/October cruises.

the rainy season that were analyzed in this study came from April 2009 aboard the B/I Orion and the small boat surveys in June 2010. Bryde's whales were sighted during all seasons examined. The small boat survey observed a Bryde's pair closely followed by another individual Bryde's whale. Blue whales were also sighted in groups as well as individuals. The blue whales observed west of Fernandina Island in 2011 were believed to be feeding, given the repetitive peduncle arches and dives.

Sperm whales were also one of the more commonly identified odontocetes, which was encouraging given the multiple decades in which sperm whales appeared to have vacated the Galápagos Marine Reserve and other Ecuadorian waters (Whitehead et al., 1996). Between 1999 and 2008, just one sperm whale sighting was recorded ${ }^{9}$. From 2009-2011, 15

${ }^{9}$ Kinzey, D., Gerodette, T., Barlow, J., Dizon, A., Perryman, W. and Olson, P. (2000) Marine mammal data collected during a survey in the Eastern Tropical Pacific Ocean aboard the NOAA ships McArthur and David Starr Jordan, July 28-December 9, 1999. NOAA Technical Memorandum NMFS: NOAA-TMNMFS-SWFSC-293. National Oceanic and Atmospheric Administration. 


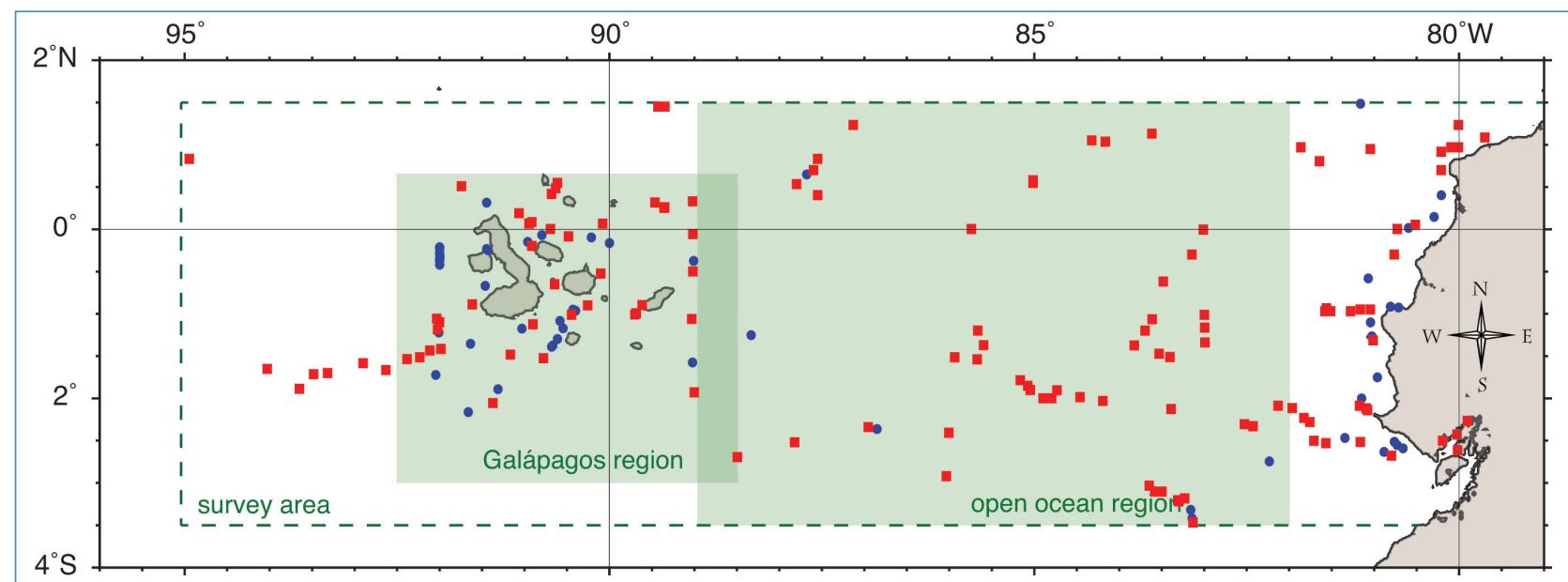

Figure 7. Balaenopteridae (blue squares, $\mathrm{n}=56$ ) and Odontocete (red squares, $\mathrm{n}=146$ ) sightings for all NOAA cruises (1999, 2000, 2003) and B/I Orion cruises (2001-2011).

sperm whale sightings were recorded. During April 2009, the sighting included at least one juvenile. Just over half of the sperm whale sightings came from within the marine reserve. The other sperm whale groups were observed in open-ocean habitat.

Using sighting rates per area effectively searched, multiple $B / I$ Orion cruise sighting rates overlap with sighting rates aboard NOAA cruises. When available, using the area effectively searched (trackline survey distance multiplied by twice the effective half-strip width) may be a more meaningful way to compare sighting rates between surveys. This finding also suggests that there were no drastic changes in overall cetacean abundance between the 1999 NOAA cruise and the 2011 B/I Orion cruise.

The abundance estimates for striped and common dolphins using NOAA data did not agree well with the estimates made using $B / I$ Orion data. Several factors likely account for the differences. First, the group size estimates for common dolphins were on average $50 \%$ greater during NOAA surveys than $B / I$ Orion surveys. For striped dolphins the NOAA survey estimates were on average $20 \%$ greater. After accounting for this difference, estimates for the striped and common dolphin abundances calculated using NOAA survey data were still about twice as high as those calculated using $B / I$ Orion survey data. NOAA surveys also spent about $20 \%$ more time than $B / I$ Orion within the Galápagos Islands study area where cetacean sightings were twice as frequent relative to open-ocean habitat. However, even after considering these factors, it is likely that some groups of animals on the trackline were not observed during B/I Orion surveys. The probability of detecting an animal directly on the trackline or $g(0)$, relative to varying Beaufort sea states, was calculated by Barlow (2015). However, accounting for only the Beaufort sea state impact on $g(0)$ does not sufficiently explain the smaller B/I Orion abundance estimates.
The encounter rate from the April survey was 1.5 time greater than the average sighting rate for rainy September/ October surveys aboard the B/I Orion. This difference was statistically significant for raw encounter rates, however when the effects of sea state are included, the 2011 September cruise sighting rates are not statistically different from the April sighting rates. Additional surveys during the drier season months like April (including a more rigorous collection of observing conditions) would provide a greater understanding of intra-annual fluctuations in species density in this area.

One improvement that could be made to the shipsof-opportunity program aboard the B/I Orion and likely other similar programs is the use of high-power binoculars. NOAA surveys utilized more powerful binoculars ('big eye' $25 \times 150 \mathrm{~mm}$ mounted binoculars) than the $7 \times 50 \mathrm{~mm}$ hand held binoculars used by $B / I$ Orion observers. More powerful binoculars increase the distance at which cetaceans can be reliably seen from a ship. The NOAA surveys, while spending about half as much time within the survey region as the $B / I$ Orion surveys, observed about the same number of sightings as the $B / I$ Orion surveys. Given that population abundance and density estimates require a certain threshold of actual sightings for each species to be statistically viable, ships-of-opportunity programs could be substantially more cost-effective by utilizing high-power binoculars in order to increase the effective half-strip width. These high-power binoculars are only useful and will only increase the effective half-strip width of survey programs on larger ships $(>-30 \mathrm{~m})$. They also require more frequent rotation of observers to avoid fatigue, which would require more total observers to maintain a continuous search.

Higher power binoculars also enabled observers to identify species from further distances than during B/I Orion surveys. Ship avoidance by delphinids (Scott and Chivers, 2009) and lack of closing protocol (deviation from the survey track to 
approach and identify animals) during B/I Orion surveys limited the ability of observers to identify the species of cetacean groups sighted. Observers frequently noted apparent avoidance behavior when the B/I Orion approached large groups of dolphin species. On average, half of the sightings made aboard the $B / I$ Orion were identified to species whereas three-quarters of the sightings were identified to species level during NOAA cruises. A greater number of highly trained marine mammal scientists also likely improved species identification during NOAA cruises.

Beaked whales (Family Ziphiidae), a group of deepwater cetaceans difficult to observe at sea due either to ship avoidance or long dive cycle duration (Santos et al., 2001), were observed in greater numbers during NOAA surveys than surveys aboard the $B / I$ Orion. In total, 14 beaked whale sightings were made during NOAA cruises (1999-2000). Just one recorded beaked whale sighting was made aboard the $B / I$ Orion (September 2009). Given the elusive nature of these animals, it is likely that observers were simply not able to identify beaked whales before they left the surface, a trend reflected in the greater proportion of unidentified sightings made during B/I Orion cruises.

\section{Conclusion}

Ships-of-opportunity programs can effectively supplement dedicated marine mammal surveys and provide an economical means to obtain data from areas of mid to low marine mammal density. Key considerations regarding shipsof-opportunity surveys resulting from this analysis include the following:

- Ships-of-opportunity could readily increase the quantity of sightings and species identifications they provide by including high-powered binoculars;

- Measuring the distance between observer and marine mammal sightings provides an important means for estimating the actual area of ocean surveyed and provides a more quantifiable estimate of sighting rates and marine mammal densities;

- At least one expert observer in field identification of cetaceans should participate on each observer watch during opportunistic surveys. Much of what we know about marine mammal distributions is based on visual identifications at sea, so accurate and reliable identifications are paramount;

- Elusive and more difficult to identify species such as beaked whales are the most likely cetaceans to be under-represented in opportunistic surveys;

- Combining ships-of-opportunity with dedicated surveys can provide a cost effective means of exploring and monitoring marine mammal distributions. Since marine mammals can be observed visually at the surface, particularly on ships that do not pass out of the observable range within typical dive cycle durations (ships not traveling faster than 8-12 knots) observers need not interfere with the ship's other activities.

- Monitoring marine mammal distributions will become increasingly important as the scientific community continues to assess the impacts of a changing climate on the world's oceans. Ships like the $B / I$ Orion already engaged in regularly repeated surveys provide an excellent opportunity to assess potential trends and fluctuations in marine mammal populations, particularly in areas that are less well represented in marine mammal surveys due to low cetacean densities. These kinds of programs should be actively utilized for future survey work.

\section{Acknowlegments}

The authors would like to extend our gratitude to the Oceanographic Institute of the Ecuadorian Army (INOCAR) for making space available for our observers during its oceanographic cruises. We would also like to thank the officers, crew, and scientists aboard the B/I Orion for their help in coordinating survey activities. We are very thankful to the NOAA Southeast Fisheries Science Center, especially Dr. Keith Mullin, for providing their expertise and time. The Ecuadorian Foundation for the Study of Marine Mammals (FEMM) helped coordinate volunteers and conduct survey work, for which we are very grateful. Students from the Universidad San Francisco de Quito, Texas A\&M University including Christopher Paul, and other universities participating in INOCAR cruises were invaluable as survey observers and their enthusiasm. We are grateful for the financial support provided by the PADI Foundation and Texas A\&M University.

\section{References}

Alava, J.J., Barragán, M.J., Castro, C. and Carvajal, R. (2005) A note on strandings and entanglements of humpback whales (Megaptera novaeangliae) in Ecuador. Journal of Cetacean Research and Management 7(2): 163-168.

Au, W.K. and Perryman, W.L. (1985) Dolphin habitats in the eastern tropical Pacific. Fishery Bulletin 83(4): 623-643.

Barlow, J. (2015) Inferring trackline detection probabilities, $g(0)$, for cetaceans from apparent densities in different survey conditions. Marine Mammal Science 31(3): 923-943.

https://doi.org/10.1111/mms.12205

Buckland, S.T., Anderson, D.R., Burnham, K.P. and Laake, J.L. (1993) Distance sampling: Estimating abundance of biological populations. Chapman and Hall, London, UK.

Buckland, S., Anderson, D.R., Burnham, K.P., Laake, J., Borchers, D. and Thomas, L. (2001) Introduction to distance sampling: estimating abundance ofbiologicalpopulations. Oxford University Press, Oxford, UK. https://doi.org/10.1007/97894-011-1572-8 https://doi.org/10.1007/978-94-011-1574-2 
Chavez, F.P. and Barber, R.T. (1987) An estimate of new production in the equatorial Pacific. Deep Sea Research Part A. Oceanographic Research Papers 34(7): 1229-1243. https://doi.org/10.1016/0198-0149(87)90073-2

Clarke, R. (1962) Whale observation and whale marking off the coast of Chile in 1958 and from Ecuador towards and beyond the Galápagos Islands in 1959. Norsk Hvalfangsttid 51: 265-287.

Clarke, R., Fernando, F., Obla, P. and Patricia, B. (2001) Ballenas y delfines observados por la expedición Ballenas Libres durante el crucero oceanográfico CO-II-01 entre Guayaquil y las Islas Galápagos del 17 de Septiembre al 9 de Octubre 2001. Acta Oceanografica del Pacifico 11(1): 1-4.

Denkinger, J., Oña, J., Alarcón, D., Merlen, G., Salazar, S. and Palacios, D. (2013) From whaling to whale watching: Cetacean presence and species diversity in the Galápagos Marine Reserve. Science and Conservation in the Galápagos Islands 1: 217-235. https://doi.org/10.1007/978-1-4614-5794-7_13

Félix, F. (1997) Organization and social structure of the coastal bottlenose dolphin Tursiops truncatus in the Gulf of Guayaquil, Ecuador. Aquatic Mammals 23(1): 1-16.

Félix, F. and Haase, B. (2001) The humpback whale off the coast of Ecuador, population parameters and behavior. Revista de Biología Marina y Oceanografía 36(1): 61-74.

https://doi.org/10.4067/S0718-19572001000100006

Félix, F. and Haase, B. (2005) Distribution of humpback whales along the coast of Ecuador and management implications. Journal of Cetacean Research and Management 7(1): 21-31.

Félix, F., Munoz, M., Falconi, J., Botero, N. and Haase B. (2011). Entanglement of humpback whales in artisanal fishing gear in Ecuador. Journal of Cetacean Research and Management Special Issue 3: 285-290.

Fiedler, P.C. and Reilly, S.B. (1994) Interannual variability of dolphin habitats in the eastern tropical Pacific. II: Effects on abundances estimated from tuna vessel sightings, 1975-1990. Fishery Bulletin 92: 451-463.

Lerczak, J.A. and Hobbs, R.C. (1998) Calculating sighting distances from angular readings during shipboard, aerial, and shore-based marine mammal surveys. Marine Mammal Science 14(3):590-599.

https://doi.org/10.1111/j.1748-7692.1998.tb00745.x

Loesh, H. (1966) Observación de ballenas en aguas ecuatorianas. Informe de datos, mayo de 1963 y enero-febrero de 1964. Boletín Cientifico y Técnico 4: 1-18.

Mullin, K. and Fulling, G. (2004) Abundance of cetaceans in the oceanic northern Gulf of Mexico, 1996-2004. Marine Mammal Science 20: 787-807.

https://doi.org/10.1111/j.1748-7692.2004.tb01193.x
Palacios, D., Gerrodette, T., Herrera, J.C., García, C., Soler, G.A., Avila, I.C., Bessudo, S., Hernandez, E., Trujilo, F. and González, I.F. (2009) Cetacean distribution and relative abundance in Colombia's Pacific EEZ from survey cruises and platforms of opportunity. Journal of Cetacean Research and Management 12(1): 45-60.

Santos, M.B., Pierce, G.J., Herman, J., Lopez, A., Guerra, A., Mente, E. and Clarke, M.R. (2001) Feeding ecology of Cuvier's beaked whale (Ziphius cavirostris): a review with new information on the diet of this species. Journal of the Marine Biological Association of the UK 81(4): 687-694.

https://doi.org/10.1017/S0025315401004386

Scheidat, M., Castro, C., Denkinger, J., González, J. and Adelung, D. (2000) A breeding area for humpback whales (Megaptera novaeangliae) off Ecuador. Journal of Cetacean Research and Management 2(3): 165-171.

Scott, M.D. and Chivers, S.J. (2009) Movements and diving behavior of pelagic spotted dolphins. Marine Mammal Science 25: 137-160. https://doi.org/10.1111/j.1748-7692.2008.00241.x

Smith, S.C. and Whitehead, H. (2000) The diet of Galapagos sperm whales (Physeter macrocephalus) as indicated by fecal sample analysis. Marine Mammal Science 16: 315-325. https://doi.org/10.1111/j.1748-7692.2000.tb00927.x

Taylor, B.L., Baird, R., Barlow, J., Dawson, S.M., Ford, J., Mead, J.G., Notarbartolo di Sciara, G., Wade, P. and Pitman, R.L. (2008). Physeter macrocephalus. The IUCN Red List of Threatened Species 2008: e.T41755A10554884.Downloaded on 12 January 2017.

Thomas, L., Buckland, S.T., Rexstad, E.A., Laake, J.L., Strindberg, S., Hedley, S.L., Bishop, J.R.B., Marques, T.A. and Burnham, K.P. (2010) Distance software: design and analysis of distance sampling surveys for estimating population size. Journal of Applied Ecology 47: 5-14. https://doi. org/10.1111/j.1365-2664.2009.01737.x

Townsend, C.H. (1935) The distribution of certain whales as shown by the logbook records of American whaleships. Zoologica 16: 133-144.

Whitehead, H. and Waters, S. (1992) Population structure of female and immature sperm whales (Physeter macrocephalus) off the Galapagos Islands. Canadian Journal of Fisheries and Aquatic Sciences 49: 78-84. https://doi.org/10.1139/f92-009

Whitehead, H., Christal, J. and Dufault, S. (1996) Past and distant whaling and the rapid decline of sperm whales off the Galápagos Islands. Conservation Biology 11(6): 1387-1396. https://doi.org/10.1046/j.1523-1739.1997.96246.x

Williams, R., Hedley, H.L. and Hammond, P.S. (2006) Modeling distribution and abundance of Antarctic baleen whales using ships of opportunity. Ecology and Society 11(1): 1-28. https://doi.org/10.5751/ES-01534-110101 